\title{
0 aldeamento do Maracanã: os índios e a sociedade colonial na capitania do Pará (Século XVII)*
}

The aldeamento do Maracanã: indians and colonial society in the captaincy of Pará (XVII Century)

\author{
Rafael Ale Rocha* \\ Universidade Federal do Amazonas (UFAM), Manaus, AM, Brasil
}

\begin{abstract}
RESUMO: O presente artigo pretende analisar o aldeamento do Maracanã, instalado na costa da capitania do Pará, durante o século XVII. Com base em documentos diversos, observaremos as relações políticas que envolveram os habitantes do aldeamento. Abarcando conflitos, negociaçóes e interesses múltiplos, reuniam agentes diversos (índios, lideranças indígenas, jesuítas, autoridades coloniais, elites locais, entre outros), mas, no que se refere à estabilidade da comunidade, dependiam fundamentalmente da concórdia entre os oficiais indígenas coloniais e os demais índios.
\end{abstract}

PALAVRAS-CHAVE: Amazônia Colonial. Aldeamentos. Lideranças indígenas coloniais.

\begin{abstract}
This article aims to analyze the aldeamento do Maracanã, located on the coast of the captaincy of Pará, during the XVII century. Based on several documents, we intend to analyze the political relations that involved the villagers. Encompassing conflicts, negociations, and multiple interests, brought together diverse agents (Indians, indigenous leaders, Jesuits, colonial authorities, local elites, among others), but, about the community stability, fundamentally were dependent on the agreement between colonial indigenous officers (the mentioned leaders) and the other Indians.
\end{abstract}

KEYWORDS: Colonial Amazon. Aldeamentos. Colonial indigenous leaders.

\footnotetext{
*Este artigo contou com o apoio financeiro da Universidade Federal do Amazonas e da Coordenação de Aperfeiçoamento de Pessoal de Nível Superior.

${ }^{\star}$ Professor da Universidade Federal do Amazonas (UFAM), Manaus, AM, Brasil. Doutor em História pela Universidade Federal Fluminense (UFF), Niterói, RJ, Brasil. E-mail: rafael_ale_rocha@yahoo.com.br. https://orcid.org/0000-0002-3516-5783.
} 


\section{Introdução}

Em 1688, a Mesa de Consciência e Ordens debatia uma solicitação atribuída ao índio principal do aldeamento do Maracanã Francisco de Sousa, filho do antigo principal do mesmo aldeamento Lopo de Sousa, segundo a qual requeria que sua habilitação ou "provanças" fosse realizada na Corte - investigação referente à mercê do hábito da Ordem de Avis que alegava ter recebido monarca. Embora dois conselheiros sugerissem que a inquirição fosse realizada em São Luís, visto que o aldeamento em questão estava localizado na costa do Pará entre esta cidade e Belém (capitais, respectivamente, das capitanias do Maranhão e do Pará), o tribunal recomendou atender ao pedido caso os serviços do suplicante fossem "de qualidade" - o que, em resolução firmada na lateral da consulta, foi acatado pelo monarca.

A solicitação justificava-se destacando os serviços ("e que Vossa Majestade por seus serviços lhe fez mercê do hábito de Avis"), o fato de ser conhecido na Corte ("e nesta Corte tem testemunhas que bem o conhece") e a ascendência do índio, qual seja, "filho de Dom Lopo de Sousa, índio de nação, por pais e avós"; e requisitava, ainda, a dispensa de um impedimento que teoricamente lhe impossibilitava a conquista da almejada mercê: "[...] e constando por elas [investigação ou provanças] não ter outro impedimento mais que o de índios que foram gentios, mandar se lhe consulte o impedimento para também o dispensar” (ANTT, 1688, Letra F, m. 1, n.o 17). Se os citados dois conselheiros sugeriram que a mencionada investigação fosse realizada em São Luís, onde "se achará melhor notícia [sobre o suplicante] do que nesta Corte”, não era a primeira vez que um membro da família deste índio aparentemente procurava proximidade com a monarquia. Nesse sentido, uma petição atribuída ao mesmo principal Lopo de Sousa chegara com dois parentes seus ao reino, em 1655, e fora submetida ao Conselho Ultramarino pelas mãos do procurador da capitania do Pará Manuel Guedes Aranha - segundo a qual requisitava a sucessão de seus postos e mercê em favor do filho Francisco, o cargo de principal e o hábito da Ordem de Cristo, e postos militares e ajuda de custo aos referidos dois parentes. A solicitação, é importante informar, foi acatada por resolução régia (em parecer na margem da consulta) (AHU, 1644, cx. 3, doc. 369).

Essa narrativa nos remete a algumas questões: quais serviços possibilitaram a instalação dessa família nos cargos de poder do aldeamento em estudo? Por quais motivos a monarquia e/ou a Corte aparentemente exercia certo grau de atração sobre a mesma família? No que se refere à estabilidade do aldeamento do Maracanã, e limitando nosso estudo ao século XVII, nosso principal objetivo é demonstrar que se a ligação com a monarquia e/ou outros agentes externos era evidente, especialmente membros da elite local, de suma importância era a concórdia entre o chefe e os demais índios do aldeamento. Pelo menos duas evidências, que passamos a detalhar nas páginas que se seguem, ilustram esse fato: o papel de Lopo de Sousa na construção da legislação indigenista e as concessões das chamadas mercês régias àquela família

\section{Os Sousa, a política indigenista, a elite local e os jesuítas}

A historiografia já destacou o impacto das políticas indígenas, em especial por meio da "resistência" bélica ou mesmo "aceitação", sobre as políticas indigenistas no Estado do Brasil. Tratava-se de um impacto sobre a política imperial institucionalizada, isto é, sobre a legislação propriamente dita (MONTEIRO, 1994, p. 35-42; PERRONE-MOISÉS, 2006, p. 129). Para a Amazônia 
Portuguesa ou Estado do Maranhão e Grão-Pará, a historiografia clássica apresenta a legislação indigenista como resultado da ação mediadora praticada pela Coroa no sentido de sanar conflitos entre colonos e missionários ( grosso modo) jesuítas pelo controle da mão de obra indígena, além de responder, acrescentaríamos, ao projeto de ocupação do vale amazônico por via dos aldeamentos missionários. Sem desmerecer o impacto causado pelo antagonismo entre os referidos dois grupos (moradores e jesuítas), Rafael Chambouleyron destaca que a supervalorização da polarização em questão pode esconder outras diversas relações, não necessariamente conflituosas (catequese, sacramentos, ensino, entre outras), que os envolveram (CHAMBOULEYRON, 2003, p. 182-200).

Se o conflito entre moradores e jesuítas não exauria o quadro, a partir do trabalho de Mathias Kiemen, tornou-se evidente que estavam presentes interesses e agentes diversos durante o processo de construção da legislação indigenista, como, por exemplo, os prelados das demais ordens missionárias (franciscanos, carmelitas, mercedários), o clero secular (os bispos, os vigários gerais, os padres seculares), os governadores (ou ex) e as elites locais ou as câmaras de São Luís e Belém - especialmente através dos seus procuradores, constantemente, enviados ao reino (KIEMEN, 1954). Nesse sentido, em relação à segunda metade do século XVII, Chambouleyron afirma que a mencionada legislação "estava profundamente ancorado na sociedade e realidade colonial" (CHAMBOULEYRON, 2005, p. 255, tradução nossa).

Portanto, visto que elaborada a partir de discussões baseadas em informações muitas vezes recolhidas entre pessoas com larga experiência naquela conquista, a política indígena, seja por via da resistência bélica explícita ou investindo na luta por normas favoráveis por meios institucionais, também contribuía - isto é, recorrendo à monarquia. Inclusive, nesse sentido, o autor cita o Maracanã e o seu principal Lopo de Sousa como exemplo, visto que, durante a segunda metade do século XVII, o índio solicitou o hábito da Ordem de Cristo, conflitou contra o jesuíta Antônio Vieira e, entre fins dos seiscentos e início dos setecentos, o aldeamento legalmente conquistou a isenção da concessão de índios aos serviços dos colonos e missionários (CHAMBOULEYRON, 2005, p. 255-259). Nossa contribuiçã̃o pretende demonstrar, nas páginas que se seguem, que a atuação do chefe - junto à monarquia e à elite local — também possui relação com a legislação indigenista aplicada em todo o Estado.

Ilustrar a imagem apresentada pela literatura da época (juristas, teólogos, tratadistas) sobre a sociedade e a monarquia talvez ajude a entender a questão. Nesse sentido, dentre suas principais funçôes, a monarquia era responsável pela justiça, isto é, por um lado, garantir a ordem e a paz por via da conservação da hierarquia social e, por outro, arbitrar conflitos entre esferas de interesses (XAVIER; HEPANHA, 1998b, p. 114-116; OLIVAL, 2001, p. 15-32). A concessão das chamadas mercês régias cumpria essa função, visto que institucionalizava a hierarquia e cimentava as relações políticas entre súditos e soberanos, usualmente, alargadas a todo o reino por meio de “intermediários”. Esses vínculos, cabe informar, eram constantemente reiterados, pois, perpetuando-se a ligação entre os vassalos e a monarquia, a remuneração de um serviço normalmente previa a execução de um novo (como forma de agradecimento) (XAVIER; HEPANHA, 1998a, p. 339-348; OLIVAL, 2001, p. 15-32). Contudo, no caso da chefia indígena em estudo, o estabelecimento dessas relações recíprocas, envolvendo interesses convergentes (aliados) por vezes opostos a interesses divergentes (inimigos), não se fazia exclusivamente com a monarquia, mas com agentes externos diversos e, sempre, com a sua própria comunidade. Portanto, como veremos, associado e assemelhado a membros da elite local, Lopo de Sousa conflitara contra jesuítas no contexto da 
elaboração da legislação indigenista e integrava a imagem do conquistador e integrante dos primeiros povoadores, que, como mostra vasta bibliografia, era argumento importante para a consolidação da elite local (monopólio de cargos especialmente) em várias capitanias da América Portuguesa. Como conjugava interesses variados, explica-se o termo "rede" vinculado às referidas relaçóes recíprocas ou clientelares. Vejamos.

Já em 1647 se tem notícia de um certo Lopo assinando um termo - com uma cruz, "por não saber ler nem escrever" - por meio do qual afirmava que estava "formando" um aldeamento, num sitio chamado Mocajuba, a convite de um vigário chamado Manuel Freire da Maia. O termo, registrado no livro da fazenda da capitania do Caeté, garantia que o índio e "seus vassalos" se tornariam católicos e trabalhariam para o donatário e moradores da capitania por pagamentos, motivo pelo qual Lopo já havia recebido 29.660 réis (SGL, 1646, Res 2-E-1, f. 69 e 69v.; CARVALHO JÚNIOR, 2017, p. 118). Segundo Serafim Leite, no decorrer do século XVII, o aldeamento mudou de lugar em pelo menos duas ocasióes até 1689, contava com índios pacajás em seu núcleo originário e, abandonada pelos missionários algumas vezes, só se tornou jesuíta permanentemente ("até o fim”, segundo o autor) a partir de 1702 (LEITE, 2000, t. III, p. 289-290). Contudo, para as questões relativas tanto à nação "originária” quanto à jurisdição dos jesuítas sobre a comunidade, o protagonismo dos índios (principalmente do seu principal) inegavelmente fez-se presente.

No que se refere à nação, conforme diário de viagem elaborado em 1656, o jesuíta João de Souto Maior apresentava um principal do Maracanã chamado Copaúba que o auxiliava a descer parentes àquele aldeamento durante jornada ao rio Pacajá - na qual comandava, no dizer do padre, os “tapejaras”. Esse principal Copaúba, como atesta documentos posteriores, era Lopo de Sousa. Alguma relação conflituosa foi estabelecida entre o jesuíta e o índio, pois, além de reputar Copaúba como orgulhoso, Souto Maior afirmava "que eu contra a minha vontade [o] levei nesta jornada" (BPE, 1656, CXV/2-11, f. 66-74v.). Quanto aos "tapejaras”, o termo possivelmente referia-se aos “tapijaras”. Almir Carvalho Jr., com base na obra setecentista do jesuíta João Daniel, destaca que o termo tapijara poderia ser a corruptela do nome tabajara, isto é, lembrava a origem tupi desses índios. Isso porque, quando desejavam obediência ou havendo dúvidas sobre quem era o "mais principal”, os índios recorriam ao termo em questão. De fato, conforme o jesuíta, tapijara identificava os “descendentes dos primeiros fundadores” dos aldeamentos e, também, distinguiam-nos dos recém-descidos: os chamados barés ou o termo injurioso ocapira, que, por vezes, identificava um gênero de escravidão entre os índios. Esses últimos nomes eram vergonhosos, segundo Daniel, para os tapijaras (CARVALHO JÚNIOR, 2017, p. 2010). Aliás, o mesmo jesuíta afirmava que o aldeamento em questão foi povoado originalmente por tupinambás (DANIEL, 2004, p. 367).

Nesse sentido, tendo em mente a migração conjunta de vários grupos tupis entre fins do século XVI e início do XVII do norte do Estado do Brasil ao Maranhão e Pará - tupinambás, tabajaras, caetés, potiguaras - e o fato de os pacajás pertencerem ao tronco tupi (BETTENDORFF, 1990, p. 97-102), cabe perguntar se esses habitantes do rio Pacajá também não eram descendentes daqueles migrantes oriundos de Pernambuco e adjacências. Ora, conforme John Monteiro, muitos grupos indígenas, dentre eles, aqueles tupis que rumaram ao Maranhão e Pará, estabeleceram "novas configurações étnicas e sociopolíticas” durante o contexto pós-conquista, destacando-se aquelas articuladas de algum modo ao projeto colonizador - sejam como aliados, inimigos ou refugiados (MONTEIRO, 2001, p. 63). 
Sobre as legislaçóes indigenistas aplicadas à A mazônia Portuguesa, promulgadas nos anos de 1647 e 1648, que visavam garantir a liberdade dos índios aliados, destituir o poder temporal dos administradores leigos sobre os aldeamentos (os chamados capitães de aldeia), regular o tempo de serviço dos índios e normatizar os salários dos mesmos, foi antecedida por "debates” (opinióes, sugestôes, críticas), dos quais participaram o governador Francisco Coelho de Carvalho, o vigário geral Matheus de Sousa Coelho, a câmara de São Luís, o provedor Manuel Pita da Veiga, o frei franciscano Cristóvão de Lisboa, entre outros agentes. Com exceção da câmara, que sugeria a abertura dos sertões para o resgate, no geral, as autoridades recomendavam a multiplicação das operaçóes de descimento e a proibição do cativeiro por resgates, em função dos constantes desrespeitos às normas existentes para tal e à costumeira prática de cativar (além dos resgatados) índios aliados/amigos, pois, conforme essas autoridades, a prática esvaziara os aldeamentos do Estado (LIVRO..., 1948, p. 17-19; KIEMEN, 1954, p. 60-69; ROCHA, 2013, p. 65-67). "Sem o gentio", afirmava o governador Coelho de Carvalho, que nos anos 1640 intervira junto à monarquia para garantir mercês a índios (AHU, 1644, cx. 3, doc. 236), "não é possível vivermos nestas partes porque delas [almas dos índios] depende a defensa deste Estado e a nossa conservação” (AHU, 1644, cx. 2, doc. 218). Ora, a restauração do Maranhão, a expulsão dos holandeses que ocuparam a ilha entre 1641 e 1644, era em grande parte reconhecidamente obra dos indígenas aliados - conforme atesta o padre Francisco Araújo, a câmara de S. Luís e o próprio Coelho de Carvalho (AHU, 1644, cx. 2, docs. 191, 210 e 213). Observamos que foi justamente nesta conjuntura que certo Lopo, possivelmente Copaúba, reuniu índios para formar um aldeamento.

Sobre a formação da legislação indigenista dirigida ao Estado, sabe-se que os conflitos ocorridos entre Portugal e outras potências estrangeiras naquelas partes - nomeadamente, holandeses (décadas de 1640-50) e franceses (anos 1680-90) — influíram diretamente nos debates que antecediam à promulgação das leis indigenistas (representações, petições ou requerimentos, juntas reunidas para tal fim e consultas do Conselho Ultramarino). Quanto aos índios que atuavam nos referidos conflitos ao lado dos portugueses, receberam, especialmente na década de 40 do século XVII, mercês régias como remunerações a esses valiosos serviços - postos oficiais dos aldeamentos nos quais residiam, signos de distinção relativos às ordens militares, a sucessão destes nos seus respectivos círculos familiares, entre outras. Nessa prática, não raro, intercederam por eles algumas autoridades do Estado, que, em sua maioria, atuaram durante os combates contra os holandeses (KIEMEN, 1954, p. 56-117; CARVALHO JÚNIOR, 2017, p. 198-201; ROCHA, 2013, p. 61-73, 193-201).

Nos anos 50 dos seiscentos, Lopo de Sousa Copaúba atuou pessoalmente em conflitos que envolveram autoridades leigas e eclesiásticas. Esses embates ajudaram a consolidar a política indigenista dirigida à Amazônia. De modo geral, a política indigenista oficial explanava preocupação com as políticas indígenas - especialmente no que se refere à aliança comercial entre índios e holandeses - e a intenção de investir na missão religiosa como estratégia de conquista. Através de duas leis de 1655, o regimento do governador André Vidal de Negreiros e a de 9 de abril, a Coroa procurava, de uma vez por todas, regular as missóes e o cativeiro indígena para sanar os problemas gerados por leis recentes: a proibição incondicional da escravidão indígena promulgada em 1652, as agitações dos moradores contra os jesuítas e as novas regras para a retomada dos cativeiros estabelecidas por lei de 1653, nesse último caso, gestada a partir das intervençôes do jesuíta Antônio Vieira e, principalmente, dos procuradores das capitanias do Maranhão e Pará. A elaboração das leis de 1655 , cabe informar, foi influenciada pela destacada atuação de Vieira, superior jesuíta na 
Amazônia, em duas juntas criadas para debater a questão. Na primeira, que a mando do rei reunia grandes teólogos do reino, os procuradores do Pará e Maranhão não foram convidados a participar (mas foram "lidos” os seus papéis durante a reunião). A segunda, que visava acertar pequenos detalhes, contou com os referidos dois procuradores, Vieira e o novo governador do Estado Vidal de Negreiros (LEITE, 2000, t. VI, p. 45-53; KIEMEN, 1954, p. 81-95).

Em síntese, o regimento de Negreiros, além de conceder com exclusividade aos jesuítas o poder temporal sobre os aldeamentos e regular assuntos relativos às missóes ( $\$ 43-57)$, preocupava-se com o comércio praticado entre vassalos portugueses e "estrangeiros" no Estado - ordenando, portanto, a atração dos índios por via dos missionários para que esses indígenas estabelecessem comércio com os vassalos de S. Majestade (MENDONÇA, 1972, p. 704). Já a lei de 9 de abril delimitava detalhadas regras para o cativeiro dos índios por resgates e guerras justas, destinando aos missionários e cabos das tropas o exame da legalidade das guerras ocorridas entre os indígenas (no caso da primeira modalidade) e garantindo aos prelados e aos principais o comando dos aldeamentos - proibindo-se, assim, os chamados "capitães de aldeias" (LIVRO..., 1948, p. 25-28).

Sabe-se que, nesses debates, o desrespeito às normas do cativeiro era uma preocupação constante para Antônio Vieira, posto que, segundo o jesuíta, costumavam-se intitular como "rebelde" passível de escravidão aqueles índios que se recusavam a vender (resgates) cativos aos portugueses. Aliás, como nota Alcir Pécora, a cobiça ou o desrespeito às regras por parte dos moradores e especialmente autoridades era uma narrativa constante na argumentação do jesuíta (VIEIRA, 2008, p. 21-22), que, assim sendo, acabou aceitando ou concordando com a permissão do cativeiro indígena (ainda que restrito às rigorosas regras para evitar excessos) (KIEMEN, 1954, p. 79-117). A argumentação de Vieira, se lembrarmos dos debates ocorridos nos anos 1640, não era exatamente nova. Nesse sentido, nas cartas que enviava aos monarcas e autoridades diversas, destacava os mencionados cobiça e desrespeito às leis como entraves ao desenvolvimento da missão e dos aldeamentos. Da mesma forma, ilustrava a displicência destes moradores e autoridades em relação à proibição do gentilismo dos índios aldeados, cativos ou daqueles que fugiam das crueldades dos portugueses (VIEIRA, 2008, p. 305, 311, 320, 339, 346, 312, 319, 328, 326).

Antônio Vieira também explanava a importância crucial dos indígenas para a defesa e manutenção da conquista. Em relação a essa questão, em carta ao rei de 1753 lembrava, em provável referência à expulsão dos holandeses ocorrida em 1644, que "eles [os índios] foram os que em grande parte ajudaram a restaurá-la [a república]” (VIEIRA, 2008, p. 241). Apresentava, nesse aspecto, menção especial aos nheengaíbas da Ilha de Joanes (Marajó) que mantinham comércio com os holandeses (VIEIRA, 2008, p. 415, 423), pois, em relação a esses, "com os nheengaíbas como inimigos seria o Pará de qualquer nação estrangeira que se confederasse com eles, e com os nheengaíbas por vassalos e por amigos, fica o Pará seguro e impenetrável a todo o poder estranho" (VIEIRA, 2008, p. 422). Uma ideia central, para os propósitos de nosso estudo, era a defesa da eficácia das leis de 1655 (especialmente a de 9 de abril), que, conforme o padre, permitia a atração dos índios e a expansão da missão como um todo e a paz e aliança com os nheengaíbas em particular (VIEIRA, 2008, p. 338, 416, 424; BERREDO, 1988, p. 263-265). Esses índios, segundo a argumentação do jesuíta, eram antigos aliados que, abandonando a amizade dos lusos em função de traições portuguesas pretéritas, foram alvos de uma malograda guerra justa que reuniu "cento e dez portugueses e todos os índios do Maranhão e Pará” ou, simplesmente, "todas as forças" do Estado (VIEIRA, 2008, p. 343, 414). 
Curiosamente, a argumentação dos moradores não era muito diferente, invertendo-se somente o agente responsável pelas mazelas sofridas pelo Estado. Como demonstra Chambouleyron, por exemplo, os colonos apresentavam pelo menos três argumentos para justificar a expulsão dos jesuítas ocorrida em 1661: a “miséria” pela falta de índios, monopolizados pelos jesuítas; a “ambição” e a "cobiça” dos mesmos religiosos; e o fato de as constantes queixas dos moradores, sobre a falta de índios livres e escravos e a ambição dos padres, não serem ouvidas ou atendidas pela monarquia (CHAMBOULEYRON, 2006, p. 168-171).

Foi nessa conjuntura, lembramos, que uma petição atribuída a Lopo de Sousa Copaúba (citada na introdução deste artigo) chegou à Corte com dois parentes seus e foi levada pelo procurador do Pará, Manuel Guedes Aranha, à apreciação do Conselho Ultramarino. Aqui chegamos a um ponto crucial de nossa argumentação. Atentemos a, pelo menos, quatro ações de Guedes Aranha na Corte, ocorridas no ano de 1655 , que nos parecem interligadas: 1) intervir a favor dos moradores do Pará na construção da legislação indigenista no contexto da elaboração das referidas leis de 1655 (o regimento de Vidal de Negreiros e a de 9 de abril); 2) auxiliar os parentes de Lopo de Sousa na aquisição de mercês; 3) requerer a sua nomeação para o posto de sargento mor da tropa paga do Pará (AHU, 1672, cx. 2, doc. 98), que, na capitania, era cargo abaixo somente ao de capitão mor; e, por fim, 4) solicitar privilégios, próprios de fidalgos, dos cidadãos da cidade do Porto à elite local de Belém - instalada na câmara e no oficialato da ordenança (milícias).

A justificativa para todos esses intentos possuía um ponto comum: a restauração (expulsão dos holandeses do Maranhão em 1644) e/ou os demais conflitos sucedidos contra os flamengos. Esse fato se reveste de grande importância para os debates sobre a legislação indigenista, pois dentre as justificativas invocadas pela câmara de Belém em correspondência a Antônio Vieira e para solicitar o perdão real (referente ao motim de 1661) constavam as ações dos paraenses "conquistadores e povoadores", respectivamente, nos embates contra os "inimigos da parte do norte" (dentre eles holandeses) na região dos rios Gurupá e Tucujú (durante as décadas de 1620-1630) e no Cabo Norte. Ou seja, como destacou Chambouleyron, consideravam a escravidão indígena um "direito" de conquista (CHAMBOULEYRON, 2006, p. 172; BERREDO, 1988, p. 252). Da mesma forma, as demais solicitações destacavam: "todas as guerras em que houve com os holandeses" (AHU, 1644, cx. 3, doc. 369), no caso de Lopo de Sousa; que Guedes Aranha agiu "acudindo a todos os rebates de inimigos assim nativos como estrangeiros” (AHU, 1672, cx. 2, doc. 89), em relação à sua solicitação do posto de sargento mor; e a consideração "de largarem [os paraenses] suas casas, famílias e fazendas por irem ajudar a recuperar a dita cidade [São Luís] e lançar dela os holandeses" (AHU, 1672, cx. 2, doc. 95), no que tange à petição pelos privilégios dos cidadãos do Porto.

Sabe-se que, com exceção das questões relativas à legislação indigenista, todas as demais solicitações foram atendidas, tornando a conquista e a restauração justificativas constantemente lembradas durante a primeira metade do século XVIII, quando os privilégios adquiridos eram ameaçados por autoridades como ouvidores e governadores, e consideradas importantes para a consolidação da imagem corporativa vinculada à elite local e de sua identidade - grupo incrustado nos oficialatos da câmara de Belém e da ordenança do Pará (ROCHA, 2018). Especialmente no caso de Guedes Aranha, o único natural da região a ocupar o cargo de sargento mor durante a segunda metade do século XVII (até onde se sabe), que recebeu o hábito da Ordem de Santiago e se tornou capitão mor da capitania-fortaleza do Gurupá na década de 1680. Para obter o posto de sargento mor, posteriormente (em concurso) recorreu aos seus serviços e aos do pai - realizados nos primórdios da conquista (expulsão dos franceses do Maranhão em 1615 e os citados conflitos 
sucedidos no Gurupá, Tucujú e Cabo Norte nas décadas seguintes) e no estabelecimento de Belém com uso de cabedal particular. Quanto ao posto de capitão mor do Gurupá, o ex-governador Gomes Freire de Andrade destacava a necessidade de manter aldeamentos populosos nas proximidades da fronteira - frente ao avanço dos franceses de Caiena, que culminaria em confrontos bélicos na década de 1690 - e eleger alguém que fosse "bem reputado com o gentio, e que dele [do gentio] havesse inteiro conhecimento"; caso de Aranha, que possuía "muitos escravos, e grande autoridade com o gentio; tanta que eles lhe chamam Pai; e liberal com eles, muito zeloso e ativo" (AHU, 1644, cx. 7, doc. 784).

Retomando o motim contra os jesuítas, quando, em janeiro de 1661, Copaúba foi chamado à Belém por Antônio Vieira e lá preso e enviado posteriormente à fortaleza do Gurupá, uma petição atribuída aos índios do Maracanã e outra de autoria da câmara de Belém foram entregues ao governador D. Pedro de Melo (em São Luís). Este, portanto, requisitou do ouvidor do Estado a averiguação do ocorrido, que reuniu pareceres e testemunhos de uma gama de autoridades e demais pessoas - os pareceres do comissário franciscano, do provincial carmelita, do provincial mercedário e os testemunhos, sobre a veracidade destas informações, do antigo almoxarife do Pará, de um capitão reformado e de um certo Antônio de Matos de Sampaio. Todos, no geral, colocaram-se contra o jesuíta, destacando a falta de culpas para a prisão e a importância do aldeamento do Maracanã para a produção do sal, os rendimentos que tal produção acarretava à fazenda real, a escala das viagens - durante as quais ofertavam guias, remeiros e mantimentos - entre as duas capitanias (Maranhão e Pará) e para outros aldeamentos da região e o sustento da infantaria e dos moradores do Pará com sal e provimentos (farinha, carne e peixe). De posse desses documentos, além da carta por meio da qual Vieira atraíra Copaúba à Belém e do despacho do ouvidor sobre o caso, D. Pedro de Melo solicitou de Vieira - e, deixava claro, não ordenava - o envio do principal para avaliar as suas "culpas" e "ser castigado conforme o merecer" (BNP, 1755, cód. 645).

Além das cartas enviadas por Antônio Vieira ao rei e ao bispo do Japão, respectivamente sobre o andamento das missóes e as injustiças praticadas contra os índios em desacordo com as leis régias (a primeira publicada no Estado e a segunda interceptada pelo provincial carmelita antes do seu envio), a prisão do referido principal foi considerada a terceira causa - conforme informação do governador ao jesuíta, que prontamente a remetera ao rei (VIEIRA, 2008, p. 432-433) - para o início das agitações que, a partir de São Luís e espraiando-se ao Pará, culminou na expulsão dos jesuítas em setembro de 1661. No ano seguinte, o procurador do Pará Jorge de Sampaio Carvalho apresentava ao rei, em 25 capítulos, os motivos da expulsão; representação a qual Vieira prontamente respondeu, em texto também enviado ao monarca, capítulo por capítulo. Em ambos os documentos, precisamente nos capítulos 15 e 18, o índio Copaúba e sua prisão aparecem como personagem e evento citados para justificar ou não o motim (STUDART, 1921, p. 113-114; CIDADE, 1951, p. 209, 213). Os jesuítas acabariam por perder o poder temporal sobre a mão de obra indígena livre aldeada, mantendo-o no espiritual, pois, por lei de 1663, os aldeamentos seriam comandos pelos seus principais e a distribuição dos índios forros estaria a cargo de uma junta formada pelo padre do aldeamento e por um repartidor nomeado pela câmara (KIEMEN, 1954, p. 118-119). Em síntese, em meio aos debates que culminaram na legislação indigenista, tendo em mente a importância dos índios para a conquista, a defesa e a sustentação da colonização, o nome do principal Lopo de Sousa Copaúba aparece como agente politicamente importante e atuante no seio dos conflitos que envolveram a elite local e as mais altas autoridades leigas e eclesiásticas da colônia. Mas a que se deve, exatamente, o protagonismo deste personagem? 


\section{Os índios, as mercês e as salinas do Maracanã}

A questão faz-nos lembrar dos estudos de Maria Regina Celestino de Almeida, sobre os temiminós do Rio de Janeiro, Ronald Raminelli e Marcus Meuwese, acerca dos potiguaras de Pernambuco e adjacências. Almeida e Raminelli destacam a formação de verdadeiras linhagens indígenas, que, por respectivamente apoiarem os portugueses contra franceses (no século XVI) e holandeses (no século XVII), conquistaram de fato mercês como hábitos de Ordem Militar e patentes oficiais durante décadas ou mesmo séculos. Nesse sentido, considerando as lideranças indígenas como agentes intermediários que dificilmente abandonavam as demandas de suas comunidades, pois detinham maior poder de barganha frente ao mundo colonial — reiterando seu prestígio junto aos demais índios — já que eram reconhecidos pelas autoridades lusitanas como líderes, Almeida afirma que, conjugando significados diversos, os aldeamentos eram, também, "espaços dos índios” (ALMEIDA, 2003, p. 119, 145-168).

Se Meuwese destaca o favorecimento da comunidade - especialmente a garantia da liberdade dos índios - como a pedra angular da atuação dos chefes indígenas enquanto intermediários junto aos seus aliados holandeses (MEUWESE, 2003, p. 171-217), Raminelli afirma que o reconhecimento tanto da comunidade quanto de seus aliados portugueses eram almejados por outros chefes, parentes daqueles aliados aos flamengos, pois esses líderes só eram importantes para a monarquia enquanto pudessem mobilizar muitos indígenas à guerra. Assim sendo, numa conjuntura de conflitos no Brasil e no próprio reino, visto que Portugal estava envolvido na guerra que pôs fim à União Ibérica (1640-1663), os estigmas exigidos para a ascensão a cavaleiro de Ordem Militar - especialmente a limpeza de sangue (ser e descender de cristãos) - não foram levados em consideração para a sagração de Antônio Felipe Camarão, chefe potiguar que, capaz de comandar muitos índios, optou pela aliança com os lusos (RAMINELLI, 2015, p. 136-154). Nesse sentido, sobre Lopo de Sousa Copaúba, se o conflito com os jesuítas, a provável aliança com a elite local, a importância do aldeamento do Maracanã (salinas e entreposto) e as mercês que conquistara são elementos bem conhecidos pela historiografia, nossa contribuição visa ilustrar o redimensionamento da mercê conferida ao índio no âmbito local.

Nesse sentido, ao que parece, a resposta à pergunta acima exposta (sobre o protagonismo de Copaúba) possui ligação com as relações de reciprocidade estabelecidas pelo principal Lopo de Sousa não só com a monarquia e a elite local do Pará, mas, também e fundamentalmente, com os demais índios do aldeamento. Observamos que, para a sociedade do Antigo Regime português, os laços com a monarquia, materializados pelas mercês régias, deveriam ser perpetuados por via de um novo ciclo de serviços e recompensas. A produção das salinas e a função de entreposto próprios do Maracanã, como pretendemos demonstrar nas páginas seguintes, cumpriam tais papéis. Por isso, tornaram-se indispensáveis para a permanência do poder do chefe, que logrou a família - na pessoa do filho Francisco de Sousa - o comando do mesmo aldeamento. Contudo, como veremos, essas funções fortaleciam as ligaçôes entre o chefe e sua comunidade, pois a atuação exclusiva nas mesmas os distanciou dos intentos dos moradores e jesuítas por mão de obra e pela administração do aldeamento. Observaremos que o reconhecimento da condição de chefe indígena foi uma ação não somente da monarquia, mas, a exemplo da atuação de Guedes Aranha acima exposta, também da elite local. Parece que a existência de um interesse contrário comum - a recusa à jurisdição temporal dos aldeamentos em mãos jesuítas — contribuía nesse sentido. Contudo, como pretendemos mostrar, esse reconhecimento também visava estabelecer um líder apto a negociar com a monarquia pelos interesses e pela autonomia da comunidade. 
Assim sendo, nas cartas enviadas ao rei e/ou outras autoridades, Antônio Vieira afirmava que as referidas leis e/ou a defesa das mesmas (ou dos próprios indígenas) pelos jesuítas atraía os índios, que, como informamos, tornaram-se receosos em função das recorrentes traições dos portugueses no passado (VIEIRA, 2008, p. 293-294, 332-334, 336-337, 435-436). Quanto à Copaúba, reconhecendo sua atuação na prisão do mesmo, mas destacando a permissão e o auxílio do governador (remetendo ordem nesse sentido ao capitão mor do Pará), considerava o índio como contrário à fé, às missas e aos sacramentos, permitindo (ou incentivando com seu exemplo) aos índios seus liderados e a outros principais a perpetuação do gentilismo, especialmente, a poligamia e/ou ao sacrifício ritual. Semelhante, aliás, a já citada permissividade dos moradores e autoridades, destacava ainda o "amparo" e "favor" que Copaúba angariava de alguns portugueses ou "dos poderosos". Essa argumentação estava presente tanto na carta enviada ao rei em 1661 quanto na resposta aos capítulos do procurador Sampaio Carvalho elaborada no ano seguinte (VIEIRA, 2008, p. 433; CIDADE, 1951, p. 215-216). Em relação à desobediência das leis, naquela correspondência remetida ao monarca informava que Lopo de Sousa Copaúba cativava e vendia índios forros. Tal era a razão daqueles amparos, dos poderosos, a quem “fazia serviços” (VIEIRA, 2008, p. 433).

A argumentação dos seus contrários, os já citados documentos compilados pelo ouvidor e os capítulos de Sampaio Carvalho, praticamente invertem a de Vieira. Quanto às questóes espirituais, o comissário franciscano afirmava que "o principal mesmo tocava ao sino, fazendo o sinal com que costuma chamar a todos os seus filhos para a igreja” (BNP, 1755, cód. 645). No que se refere ao desrespeito às leis de 1655, o procurador assegurava que de fato os índios do aldeamento mantinham comercio com os portugueses, do qual agora "carecem” porque os jesuítas os proibiram, mas informava que os inacianos os administravam como "cativos" (STUDART, 1921, p. 114). Em síntese, Vieira e seus adversários divergiam quanto à fé do índio, mas concordavam no que se refere às relações comerciais praticadas entre os colonos e os moradores do Maracanã (embora o procurador ignorasse se o mencionado comércio correspondia à troca de mercadorias por cativos, isto é, ao resgate).

Enfim, ainda no que tange às posiçôes contrárias em jogo, cabe analisar dois elementos contraditórios entre ambos os discursos, com os quais chegamos ao fim deste artigo, que nos parecem relacionados: 1) as mercês régias recebidas pelo índio e sua família; e 2) a sua capacidade de manter a fidelidade dos demais indígenas do aldeamento. Isto é, a extensão da sua "rede de reciprocidades". De um lado, os aliados do índio claramente afirmavam que Copaúba era um cavaleiro por mercê régia devida pelos serviços prestados durante as guerras contra os holandeses, pois a referida petição atribuída aos índios do Maracanã, na conjuntura da prisão do principal, afirmava que arrancaram "o hábito de Cristo que Sua Majestade lhe [Lopo de Sousa] fez mercê" como "grande servidor na conquista e restauração deste Estado em que se achou"; a testemunha Antônio de Matos de Sampaio ainda descrevia a violência com a qual lhe tiraram o seu bastão e o "o hábito de Cristo que tinha" (com “empuxões”) (BNP, 1755, cód. 645); “um principal dos mais abalizados do Pará, cavaleiro do hábito de Cristo”, nas palavras de Sampaio Carvalho (STUDART, 1921, p. 113).

Tanto os pareceristas e as testemunhas compilados pelo ouvidor quanto o procurador do Pará eram unânimes em considerar que, em função da produção das salinas e do papel de entreposto atribuído ao aldeamento, o principal continuava a servir a V. Majestade, além de destacarem os grilhões com os quais o índio fora preso. Era claro que esses serviços executados pelos índios do aldeamento, conforme tal argumentação, eram conduzidos pelo principal e, em função da prisão 
dele, estavam ameaçados, porque os filhos do chefe e os índios de sua nação - "escandalizados" ou "amotinados" - fugiram para os "matos”. A ameaça era ainda maior porque quatro outros aldeamentos (segundo a petição atribuída aos índios do Maracanã) integravam parentes de Copaúba. Por outro lado, na carta ao rei de 1661 e na resposta aos capítulos de Sampaio Carvalho, Antônio Vieira não referenciava a mercê concedida ao índio e garantia que as mencionadas fugas, de fato, não ocorreram, mas seculares e eclesiásticos persuadiram alguns índios (ou pelo menos tentaram) a executarem um levante (VIEIRA, 2008, p. 433; CIDADE, 1951, p. 214-215).

Contudo, a opinião das autoridades instaladas na Corte, no que se refere à mercê angariada por Lopo de Sousa, divergia da dos locais, pois se em 1647 o capitão mor do Pará Sebastião Lucena de Azevedo já afirmava que o índio recebera de um governador ou capitão mor o hábito de Cristo "lançado" no peito (AHU, 1672, cx. 1, doc. 65), a consulta do Conselho Ultramarino de 1655 destacava que o hábito de Cristo - que assim como o posto de principal deveria suceder do pai Lopo ao filho Francisco - "é somente no vestido", além de sugerir averiguar junto à Mesa de Consciência e Ordens, em relação às normas de concessão, a "forma em que se procedeu quando se lhe lançou o hábito" (AHU, 1644, cx. 3, doc. 369). Sabe-se que, durante a década de 1640, foram dados aos índios símbolos e outras benesses relacionadas às ordens militares, em substituição às almejadas mercês, quando, após esse período, tais concessões passaram a ser mais raras e mesmo recriminadas pelas autoridades metropolitanas (CARVALHO JÚNIOR, 2017, p. 193-211; ROCHA, 2013, p. 199-201). Em 1688, quando o processo de habilitação para a aquisição do hábito de Avis de Francisco de Sousa chegou à Mesa de Consciência e Ordens, caso com o qual introduzimos este artigo, não se escreveu nenhuma palavra sobre o hábito da Ordem de Cristo (nem por parte do requerimento atribuído ao índio, nem por parte daquele tribunal). Nos dois primeiros casos citados (de 1647 e 1655), contudo, as informações remetidas ao conselho destacavam, respectivamente, a autoridade e o respeito que o principal possuía sobre os demais índios do Maracanã e o importante serviço nas salinas realizados pelos habitantes do aldeamento.

Nesse sentido, o comissário franciscano, na mencionada compilação de documentos realizada pelo ouvidor do Estado, garantia que somente os índios do Maracanã sabiam fabricar o sal "pelos ter assim doutrinado o dito principal [Lopo de Sousa]”. Em síntese, conforme o testemunho de Antônio de Matos de Sampaio, o principal só consentia o governo jesuíta sobre o aldeamento no âmbito espiritual, mas não no temporal (BNP, 1755, cód. 645). Assim sendo, em sua representação contra os jesuítas, Sampaio Carvalho informava que as salinas do Maracanã, beneficiadas por conta da fazenda real, estavam ameaçadas porque os jesuítas se negavam a conceder índios do aldeamento para tal serviço. Segundo o procurador, essas salinas eram importantes porque geravam muitos rendimentos à fazenda real (e ao "bem público" no geral) e permitia o pagamento dos soldados (STUDART, 1921, p. 209).

Em réplica, por seu turno, Antônio Vieira afirmava que, por um lado, os índios "pertencentes às salinas” não “entram em repartição" e, por outro, os padres não residiam no mesmo aldeamento, mas "só o a avistavam [visitavam?]". Culpava, inversamente, o agente que, por ordem das autoridades da fazenda real, administravam as salinas do Maracanã, pois solicitava esses índios para diversos serviços “à seu arbítrio” - especialmente, tendo em mente que existiam mais índios do que o necessário para o serviço do sal, pilotos e remeiros para as viagens ao Maranhão (CIDADE, 1951, p. 209). Provava a isenção dos padres o aceite, fato presenciado por Manuel Guedes Aranha, da recusa do principal em ofertar índios do aldeamento para uma entrada no rio Tocantins (em 1659) - alegando a falta de indígenas nas salinas por motivo de doença (CIDADE, 1951, 
p. 209-210). Semelhante era a posição do também jesuíta João Felipe Bettendorff, em fins do século XVII, quando afirmava que, já sob o "governo" de Francisco de Sousa, os índios do aldeamento serviam exclusivamente nas salinas do rei, como pilotos e para o serviço "dos que governam e tem a seu cargo as salinas d'El Rey" (BETTENDORFF, 1990, p. 90, 22).

O serviço das salinas, na verdade, possibilitava o vislumbre de almejada independência aos índios do aldeamento. Nesse sentido, o Maracanã acompanhou a legislação promulgada nas décadas de 40 e 50 dos seiscentos, isto é, justificado pelo esvaziamento dos aldeamentos durante os anos anteriores, tornou-se isento das administrações particulares (os chamados "capitães de aldeia”), cabendo à fazenda real essa função. Além do sustento da tropa, os rendimentos do sal garantiam $2 / 3$ da produção para a fazenda e $1 / 3$ aos índios (AHU, 1644, cx. 2, doc. 181; cx. 4, doc. 378; 1672, cx. 3, doc. 191). Nos anos finais do século XVII, as reclamações acerca dos desmandos dos governadores relativos à solicitação de índios do aldeamento para serviços diversos foram constantes; e quando se concedeu a administração das salinas por contrato, a ideia, aparentemente revogada logo em seguida, foi amplamente criticada pelas autoridades (governador e provedor da fazenda) (AHU, 1672, cx. 3, doc. 191, doc. 290). De qualquer forma, por lei de 1702 e contrariando o estipulado no Regimento das Missóes de 1686, o aldeamento tornou-se legalmente isento da concessão de índios (repartição) aos moradores e missionários. Aliás, quando o monarca reiterou esta imunidade, nos anos 1730, o governador atribuiu à mesma isenção o desinteresse dos jesuítas e franciscanos em realizarem novos descimentos para povoar o aldeamento (LIVRO..., 1948, p. 217-218; AHU, 1672, cx. 18, doc. 1671). As autoridades, nessas conjunturas, atestavam a importância das ações de Lopo de Sousa. Conforme os governadores André Vidal de Negreiros e Gomes Freire de Andrade (na condição de ex), respectivamente sobre a administração das salinas pela fazenda real e o mencionado contrato, nas décadas de 50 e 80 dos seiscentos:

[Após sugerir a proibição da produção de sal por qualquer particular] [...] para se evitar a queixa que o principal do Maracana Lopo de Sousa poderá ter, de que com esta proibição se lhe tirem as salinas em que fabrica sal junto às de V. Majestade, não só para si, e os mais índios de sua aldeia, mas para render, será justo que se lhe dê a ele e a sua gente cem alqueires cada ano, tendo respeito a serem os que beneficiam estas salinas, só com lhe pagarem duas varas de pano que se lhe dão por mês. (AHU, 1644, cx. 4, doc. 378).

[...] [sugere nunca arrendar as salinas] por os índios que assistem nelas fazem muitas diferenças aos sobreditos [dos da Ilha de Joanes], tanto em impugnarem pelos seus privilégios como em se estimarem por melhor procedidos [...] são os bons soldados daquela costa, e fazem particular desvanecimento de que servem só a Sua Majestade, os seus principais são ordinariamente cavaleiros do hábito, sabem estimá-lo, e observam justiça para os seus súditos, que é o que não experimentam aos dos outros principais; e neste conhecimento que tenho deles me persuado que lhe será muito violenta a consideração de que servem a um particular, e que se por ela se meterem ao mato [...] (AHU, 1672, cx. 3, doc. 290).

Assim, conforme a avaliação dos dois governadores, por meio do seu principal, os índios do Maracanã visavam à apropriação de pelo menos parte do sal produzido e não somente o pagamento dos salários estipulados por lei (as duas varas de pano, conforme lei promulgada nos anos 1640). Da mesma forma, o serviço exclusivo à $S$. Majestade, a qualidade alcançada - e os principais foram simplesmente referidos como "cavaleiros do hábito" - e a relação "justa” entre o chefe e seus liderados eram elementos imbrincados e concordantes. 


\section{Considerações finais}

A proximidade com a monarquia e a condição de vassalo não afastava Copaúba de sua comunidade, mas, ao contrário, provavelmente lhe permitia vislumbrar um horizonte no qual era possível a defesa legal do seu povo frente às açóes de determinados agentes externos. Isso, porque, por um lado, o índio era uma liderança alçada a certo grau de “qualidade" pelos meios institucionais (mercês régias) e, por outro lado, representava o agente intermediário entre os demais índios e a política indigenista da Coroa (origem de sua influência junto à própria monarquia); e lutou para manter esse papel frente às investidas dos jesuítas (durante o episódio do motim de 1661) e dos moradores (no caso dos contratos) pela posse do poder temporal sobre os aldeamentos.

Dependente do auxílio indígena, o estado português visava consolidar laços de vassalagem com essas lideranças, o que implicava na imbricação e influência mútua entre políticas indígenas e indigenistas e, enfim, na concessão de mercês ou graus de qualidade específicos. Em contrapartida, o líder deveria continuar respondendo às demandas do estado imperial — a defesa, o sal, o sustento da infantaria e de Belém, a função de entreposto. Essa relação de reciprocidade não se dava exclusivamente com a monarquia, mas, também, com outros agentes externos, como membros da elite local (auxilio mútuo no conflito contra Antônio Vieira e reinvenção local da mercê de cavaleiro) e, especialmente, com os seus "liderados" (isenção de serviços).

\section{Referências}

ALMEIDA, Maria Regina Celestino de. Metamorfoses indígenas: identidade e cultura nas aldeias coloniais do Rio de Janeiro. Rio de Janeiro: Arquivo Nacional, 2003.

ARQUIVO HISTÓRICO ULTRAMARINO (AHU). Fundo Maranhão. Cx. 2, docs. 181, 191, 210, 213, 218; cx. 3, docs. 236, 369; cx. 4, doc. 378; cx. 7, doc. 784. Lisboa: AHU, 1644-1690.

ARQUIVO HISTÓRICO ULTRAMARINO (AHU). Fundo Pará. Cx. 2, docs. 89, 95, 98; cx. 3, docs. 191, 290; cx. 18, doc. 1671. Lisboa: AHU, 1672-1736.

ARQUIVO NACIONAL DA TORRE DO TOMBO (ANTT). Habilitação da Ordem de Avis (HOA). Letra F, m. 1, n. ${ }^{\circ}$ 17. Lisboa: ANTT, ANO. 1 documento. [2] p. Não paginado.

BIBLIOTECA NACIONAL DE PORTUGAL (BNP). Coleção Pombalina (PBA). Códice 645. Lisboa: BNP, 1755. Não paginado.

BIBLIOTECA PÚBLICA DE ÉVORA (BPE). Códice CXV/2-11. Évora: BPE, 1656.

BERREDO, Bernardo Pereira de. Anais históricos do Estado do Maranhão. 4. ed. Rio de Janeiro: Alumar, 1988.

BETTENDORFF, João Felipe. Crônica dos padres da Companhia de Jesus no Estado do Maranhão. 2. ed. Belém: FCPTN: SECULT, 1990. Originalmente publicado em 1699.

CARVALHO JÚNIOR, Almir Diniz. Índios cristãos: poder, magia e religião na Amazônia Colonial. Curitiba: CRV,2017.

CHAMBOULEYRON, Rafael. Duplicados clamores: queixas e rebeliões na Amazônia colonial. Projeto História, São Paulo, n. 33, p. 159-178, dez. 2006.

CHAMBOULEYRON, Rafael. Em torno das missões jesuíticas na Amazônia (século XVII). Lusitana Sacra: $2^{\text {a }}$ série, Lisboa, n. 15, p. 163-209, 2003.

CHAMBOULEYRON, Rafael. Portuguese Colonization of the Amazon region, 1640-1706. 2005. Thesis (PhD in History) - Faculty of History, University of Cambridge, Cambridge, 2005.

CIDADE, Hernani (org.). Padre Antônio Vieira: obras escolhidas. Lisboa: Livraria Sá Costa/Editora Lisboa, 1951.

DANIEL, João. Tesouro descoberto no Máximo Rio Amazonas. Rio de Janeiro: Contraponto, 2004. 
KIEMEN, Mathias. The indian policy of Portugal in the Amazon Region, 1614-1693. Washington D. C.: Catholic University of America Press, 1954.

LEITE, Serafim. História da Companhia de Jesus no Brasil. Rio de Janeiro: Itatiaia, 2000. t. III-IV.

LIVRO Grosso do Maranhão. In: BIBLIOTECA NACIONAL DO RIO DE JANEIRO (BNRJ). Anais da Biblioteca Nacional do Rio de Janeiro (ABNRJ). Rio de Janeiro: BNRJ, 1948. v. 66, p. 14-295.

MENDONÇA, Marcos Carneiro de. Raízes da formação administrativa do Brasil. Rio de Janeiro: IHGB/Conselho Federal de Cultura, 1972.

MEUWESE, Marcus. "For the Peace and well-being of the country": intercultural mediators and Dutch-Indian relations in New Netherland and Dutch Brazil, 1600-1664. 2003. Thesis (Doctorate in Philosophy) - PhD Graduate Program in History, University of Notre Dame, Indiana, 2003.

MONTEIRO, John Manuel. Negros da terra: índios e bandeirantes nas origens de São Paulo. São Paulo: Companhia das Letras, 1994.

MONTEIRO, John Manuel. Tupis, tapuias e historiadores: estudos de História Indígena e do Indigenismo. 2001. Tese (Livre-Docência) - Instituto de Filosofia e Ciências Humanas, Universidade Estadual de Campinas, Campinas, 2001.

OLIVAL, Fernanda. As Ordens Militares e o Estado Moderno: honra, mercê e venalidade em Portugal (16411789). Lisboa: Estar, 2001.

PERRONE-MOISÉS, Beatriz. Índios livres e índios escravos: os princípios da legislação indigenista do período colonial (séculos XVI a XVIII). In: CUNHA, Manuela Carneiro da (org.). História dos índios no Brasil. São Paulo: Companhia das Letras, 2006. p. 115-132.

RAMINELLI, Ronald. Nobrezas do Novo Mundo: Brasil e ultramar hispânico, séculos XVII e XVIII. Rio de Janeiro: FGV, 2015.

ROCHA, Rafael Ale. A elite militar no Estado do Maranhão: poder, hierarquia e comunidades indígenas (século XVII). 2013. Tese (Doutorado em História Social) - Universidade Federal Fluminense, Niterói, 2013.

ROCHA, Rafael Ale. Elite local e fronteiras na Amazônia: instituições, sociedade e poder no Pará colonial (1700-1750). In: ENCONTRO INTERNACIONAL DE HISTÓRIA COLONIAL, 7., 2018, Mossoró. Anais [...]. Mossoró: EDUERN, 2018. p. 59-73.

SOCIEDADE GEOGRÁFICA DE LISBOA (SGL). Códice Res 2-E-1. Lisboa: SGL, 1646-1647.

STUDART, Barão de. Documentos para a história do Brasil especialmente do Ceará. Fortaleza: IHGC,1921. v. 4.

VIEIRA, Antônio. Cartas. Organização de João Lúcio de Azevedo. São Paulo: Editora Globo, 2008. t. 1.

XAVIER, Ângela; HESPANHA, Antonio Manuel. Redes clientelares. In: HESPANHA, Antonio Manuel (coord.). História de Portugal: o Antigo Regime. Lisboa: Editorial Estampa, 1998a. v. 4, p. 339-349.

XAVIER, Ângela; HESPANHA, Antonio Manuel. A representação da sociedade e do poder. In: HESPANHA, Antonio Manuel (coord.). História de Portugal: o Antigo Regime. Lisboa: Editorial Estampa, 1998b. v. 4, p. 113-140.

Data de recebimento: 30/04/2020

Data de aprovação: $27 / 10 / 2020$ 